\title{
A Nationwide Study of Prevalence Rates and Characteristics of 199 Chronic Conditions in Denmark
}

\author{
Michael Falk Hvidberg ${ }^{1} \cdot$ Soeren Paaske Johnsen ${ }^{2} \cdot$ Michael Davidsen $^{3} \cdot$ Lars Ehlers $^{1}$
}

Published online: 24 July 2019

(c) The Author(s) 2019

\begin{abstract}
Background Real-world data of disease prevalence represents an important but underutilised source of evidence for health economic modelling.

Aims The aim of this study was to estimate nationwide prevalence rates and summarise the characteristics of 199 chronic conditions using Danish population-based health registers, to provide an off-the-shelf tool for decision makers and researchers. Methods The study population comprised all Danish residents aged 16 years or above on 1 January $2013(n=4,555,439)$. The study was based on the linkage of national registers covering hospital contacts, contacts with primary care (including general practitioners) and filled-in out-of-hospital prescriptions.

Results A total of $65.6 \%$ had one or more chronic condition. The ten conditions with the highest degree of prevalence were hypertension (23.3\%), respiratory allergy (18.5\%), disorders of lipoprotein metabolism (14.3\%), depression (10.0\%), bronchitis (9.2\%), asthma (7.9\%), type 2 diabetes (5.3\%), chronic obstructive lung disease (4.7\%), osteoarthritis of the knee (3.9\%) and finally osteoporosis (3.5\%) and ulcers (3.5\%) in joint tenth place. Characteristics by gender, age and national geographical differences were also presented.

Conclusions A nationwide catalogue of the prevalence rates and characteristics of patients with chronic conditions based on a nationwide population is provided. The prevalence rates of the 199 conditions provide important information on the burden of disease for use in healthcare planning, as well as for economic, aetiological and other research.
\end{abstract}

\section{Introduction}

Worldwide, the financial pressures on healthcare providers are increasing. To control the rising cost of healthcare, decision makers need access to real-world evidence of current treatment patterns [1,2]. Real-world evidence of disease prevalence is important for estimating the burden of disease, cost of illness, and budget impact of new health technologies

Electronic supplementary material The online version of this article (https://doi.org/10.1007/s41669-019-0167-7) contains supplementary material, which is available to authorized users.

Michael Falk Hvidberg

michael@falkhvidberg.dk

1 Danish Center for Healthcare Improvements, Aalborg University, Fibigerstraede 11, 9220 Aalborg, Denmark

2 Department of Clinical Epidemiology, Aarhus University Hospital, Olof Palmes Allé 43, 8200 Aarhus N, Denmark

3 National Institute of Public Health, University of Southern Denmark, Oester Farimagsgade 5A, 2nd Floor, 1353 Copenhagen K, Denmark

\section{Key Points for Decision Makers}

Real-world evidence of disease prevalence is important for estimating the burden of disease, cost of illness and budget impact of new health technologies.

The Danish civil registration number provides a unique opportunity to link different types of register data for an individual patient, thus providing the best possible information on the actual treatment of chronic diseases.

Nationwide register-based prevalence statistics for 199 chronic diseases show, for most disease areas, a higher current treatment level than that expected from epidemiological research. In 2013, almost two-thirds of the entire Danish population aged 16 years or above either had a hospital diagnosis or had been in medical treatment for one or more chronic condition. 
$[3,4]$. In addition, it is important to obtain unbiased, independent documentation of disease burden, as there may be concerns with the cost-of-illness studies funded by companies [5].

The burden of chronic diseases is increasing rapidly in most countries. In Denmark, approximately $30-50 \%$ of the adult population have one or more chronic condition or long-standing illness [6-10]. Moreover, the burdens of chronic conditions are increasing [11-20]. The numbers and expenditure are growing along with an ageing population, and up to $80 \%$ of total healthcare costs can be attributed to chronic conditions [21-24]. Thus, the need for reliable and affordable estimates of the prevalence and disease burden of chronic conditions to guide decision-making in healthcare is increasing [24-26].

There are different ways to measure the prevalence of chronic conditions, varying from community-based health surveys and screening investigations to register-based studies. The choice of definitions and methods naturally affects which patients are included and hence the prevalence [27, 28].

The Scandinavian countries have an established tradition of documenting the diseases and hospital treatments of the entire population in registers; however, the registers have primarily been used to study individual conditions rather than to assess the total burden of chronic conditions [7, 24, $26,29-34]$, or to forecast drug spending to help with decision-making $[35,36]$.

The aim of the present study was to estimate the national prevalence rates and to summarise the characteristics of 199 chronic conditions using the complete Danish population aged 16 and above. To the best of the authors' knowledge, the current study is the most comprehensive, independent register-based attempt to estimate the full-population prevalence-based disease burden of chronic diseases.

\section{Methods}

\subsection{Study Population}

The nationwide study population and cohort consisted of 4,555,439 Danish residents who were alive and aged 16 years or above on 1 January 2013, of which $49.2 \%$ were men.

\subsection{The Registers}

In Scandinavian countries, general practitioners (GPs) and hospitals have a long-standing tradition of reporting diseases, treatments, medications and other treatment-related information. This is done at the micro level for national health registers. Register data are collected mostly for public administration such as claims and management, surveillance and control functions [37]. The comprehensiveness, scope and population completeness are unique to Denmark and other Scandinavian countries, enabling individual linkage across registers by means of the individual personal identification number assigned to each person [38]. The main register used was the Danish National Patient Register (NPR) [39], including the Danish Psychiatric Central Research Register [40], containing treating-physician-reported International Statistical Classification of Diseases, 10th Revision (ICD-10) hospital diagnoses. Moreover, to ensure the inclusion of patients not treated in hospitals, the National Health Service Register (NHSR) [41] and National Prescription Registry (TNPR) [42] were included in the study, since the NPR did not include diagnosis data from private specialist doctors or GPs. The NHSR contains data collected primarily for administrative purposes from health contractors in primary healthcare. It includes information about citizens, providers and health services, but minimal clinical information. Furthermore, the TNPR, comprising all prescribed and distributed medicines outside hospitals, was included to ensure the best possible identification of conditions and the representativeness thereof by clinical recommendation. All registers had a unique civil registration number for each person; furthermore, birth date, gender and other information were derived from the Danish Civil Registration System [43]. The registers used are described in more detail in other studies [44, 45]. Table 1 summarises the details of the registers used.

\subsection{The Definition of a 'Chronic Condition', Clinical Ratification and Review}

A thorough description of the distinct phases and methods used are provided elsewhere [44-46]. In short, a 'chronic condition' was defined in line with previous studies, i.e. the 'condition had lasted or was expected to last twelve or more months and resulted in functional limitations and/or the need for functional limitations and/or the need for ongoing medical care' [47-49]. An expert panel consisting of professors, medical specialists and other experts from Aalborg University, the Clinical Institute of Aalborg University at Aalborg University Hospital, the Department of Clinical Epidemiology at Aarhus University Hospital, and others was consulted using the Delphi method in order to identify which of the approximately 22,000 ICD-10 codes and conditions could be considered 'chronic' based on the definition [44]. The ICD-10 codes were aggregated to 199 conditions, yet several conditions included subgroups of ICD-10 codes; thus, some consequently contained multiple conditions within the same disease area. Subsequently, all ICD-10 conditions considered chronic by definition were included in the study in pursuit of comprising the full-population burden of chronic 


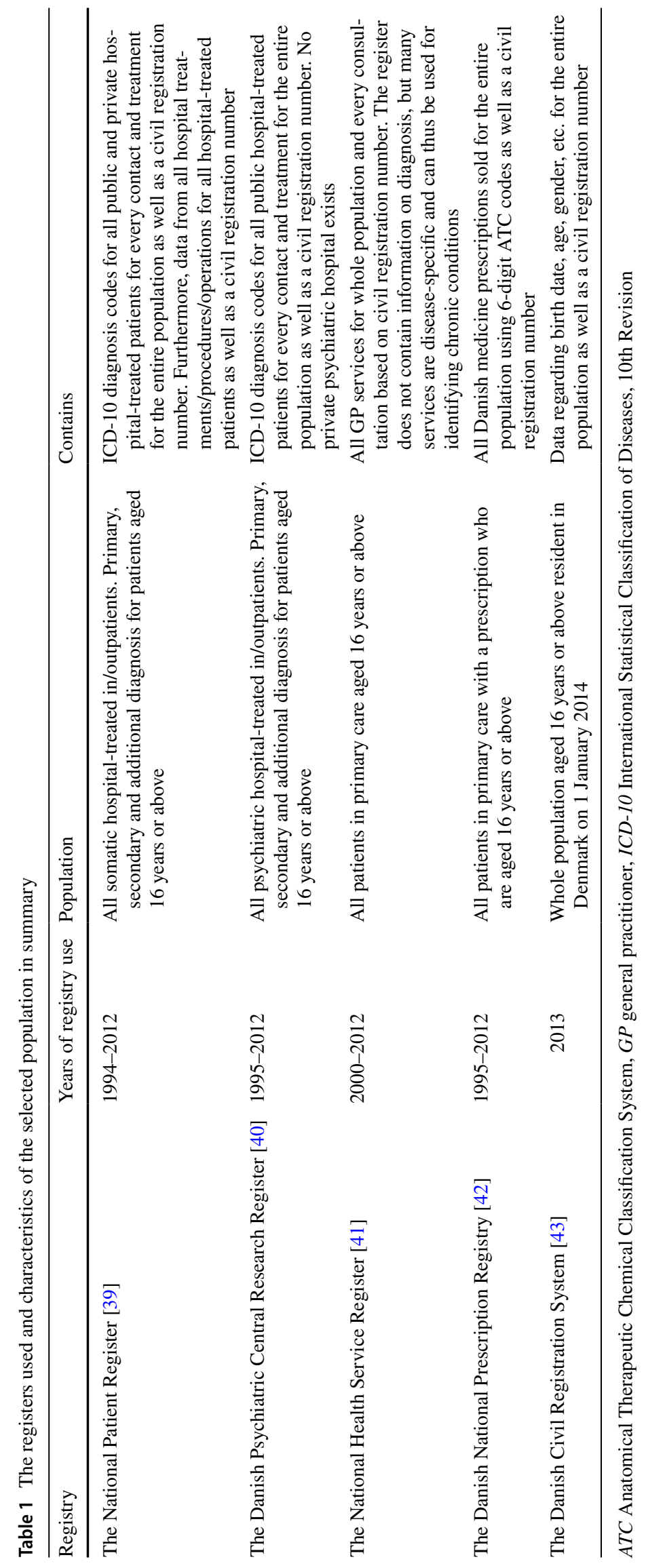


conditions. Consequently, the 199 conditions consisted of several ICD-10 codes and thus groups of illnesses.

\subsection{Data Collection: The Basis of the Data Algorithms}

Since many chronic conditions last longer than the defined 12 months, but do not last for a lifetime, the varying "chronicity' of conditions was divided into four groups of severity [44]:

- Category I: stationary to progressive chronic conditions (no time limit equals inclusion time going back from the time of interest for as long as valid data were available. In the current study, this starting point was defined by the introduction of the ICD-10 diagnosis coding in Denmark, in 1994).

- Category II: stationary to diminishing chronic conditions (10 years from register inclusion time to the time of interest).

- Category III: diminishing chronic conditions (5 years from register inclusion time to the time of interest).

- Category IV: borderline chronic conditions (2 years from register inclusion time to the time of interest).

The above four categories were designed to include the different chronic conditions when registers covered several years and still have the best possible clinical certainty that the conditions were still existing at the fixed time point of 1 January 2013. All 199 chronic conditions were divided into one of the four categories by medical specialists and experts. An algorithm was created for data collection based on the four categories, as seen in Fig. 1 for all 199 conditions and coherent ICD-10 codes. However, 35 of the 199 chronic conditions were not considered by experts to be properly representative using solely NPR diagnosis data. Thus, they created more complex algorithms using several registers besides diagnosis data, ranging from medicine and hospital treatments to GP services. For example, medicine and coherent indication codes were used to identify people with depression without a hospital diagnosis, and only when the indication codes identified the medicine used for depression, and not others such as pain treatment, etc. The same applied to GP services indicating, for example, diabetes or chronic obstructive lung disease (COPD) treatment, etc., where no hospital diagnosis was found. The details of all 199 unique definitions, their categorisation into one of the four categories and algorithms for replication can be found elsewhere $[44,45]$.

\subsection{Statistical Analysis}

Prevalence estimates were calculated in both per cent and per 1000 subjects; the proportion was calculated as the number of conditions identified divided by the total number of residents aged 16 years or above alive on 1 January 2013 $(n=4,555,439)$ multiplied by either 100 or 1000 . Thus, prevalence was calculated from a specific point in time, based on the above inclusion time periods back in time for each condition. See Fig. 1 or further details in the literature [44].

The prevalence proportions for all conditions were stratified and presented by age and sex for use by, for example, local authorities, health planners and national researchers.

Direct standardisation of age, gender and education based on the national average (i.e. using Denmark as the standard/ reference population for age, gender and education) [50] was applied to illustrate differences free of basic socio-economic effects (presented in brackets in Tables 2 and 3 and the electronic supplementary material). The gender and age (10-year intervals) variables were obtained from the Danish Civil Registration System [43], and the educational variables were obtained from the Population Education Register using Danish Education Nomenclature (DUN) classification [51].

Finally, tables were stratified geographically in the five national regions, and the mean age and standard deviation (SD) for each condition were calculated, but due to size and relevance for the international reader, geographical regions, mean age and SDs are presented in the electronic supplementary material.

All data management and data analysis were performed in SAS 9.4 (from Statistics Denmark's research servers).

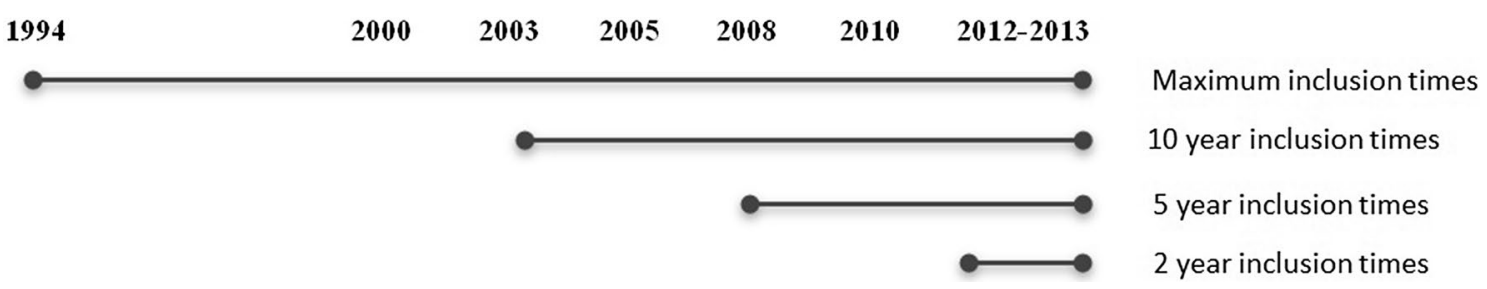

Fig. 1 The four categories of chronicity and the inclusion time periods 
Table 2 Overview of disease prevalence in Denmark: number of patients, prevalence rate (per 1000), age and gender (per cent within gender) of disease groups of conditions and chosen medicine for Denmark at 1 January 2013

\begin{tabular}{|c|c|c|c|c|c|c|c|c|}
\hline \multirow[t]{3}{*}{ Name of condition } & \multirow[t]{3}{*}{ ICD-10 code/definition } & \multicolumn{7}{|c|}{ Number and prevalence } \\
\hline & & \multicolumn{3}{|l|}{ Denmark } & \multirow{2}{*}{$\begin{array}{l}\text { Men } \\
\text { Per cent }\end{array}$} & \multirow{2}{*}{$\begin{array}{l}\text { Age } 16-44 \\
\text { (per 1000) }\end{array}$} & \multirow{2}{*}{$\begin{array}{l}\text { Age } 45-74 \\
\text { (per 1000) }\end{array}$} & \multirow{2}{*}{$\begin{array}{l}\text { Age } \\
75+(\text { pe } \\
1000)\end{array}$} \\
\hline & & $N$ & $\begin{array}{l}\text { Per } 100 \\
\text { (standa }\end{array}$ & $\begin{array}{l}0 \\
\text { rdised) }\end{array}$ & & & & \\
\hline $\begin{array}{l}\text { B-Viral hepatitis and human } \\
\text { immunodeficiency virus (HIV) } \\
\text { disease }\end{array}$ & B18, B20-B24 & 8813 & 1.9 & $(2.0)$ & 65.3 & 1.8 & 2.4 & 0.3 \\
\hline $\mathrm{C}$-Malignant neoplasms & $\begin{array}{l}\text { C00-C99; D32-D33; D35.2- } \\
\text { D35.4; D42-D44 }\end{array}$ & 229,331 & 50.3 & $(50.4)$ & 43.3 & 10.2 & 69.4 & 155.8 \\
\hline $\begin{array}{l}\text { D-In situ and benign neoplasms, } \\
\text { and neoplasms of uncertain or } \\
\text { unknown behaviour and diseases } \\
\text { of the blood and blood-forming } \\
\text { organs and certain disorders } \\
\text { involving the immune mecha- } \\
\text { nism }\end{array}$ & $\begin{array}{l}\text { D00-D09; D55-D59; D60-D67; } \\
\text { D80-D89 }\end{array}$ & 116,560 & 25.6 & $(25.7)$ & 36.3 & 13.2 & 27.3 & 80.1 \\
\hline $\begin{array}{l}\text { E-Endocrine, nutritional and } \\
\text { metabolic diseases }\end{array}$ & $\begin{array}{l}\text { E00-E14; E20-E29; E31-35; } \\
\text { E70-E78; E84-E85; E88-E89 }\end{array}$ & 877,433 & 192.6 & (192.7) & 45.6 & 43.5 & 279.6 & 501.4 \\
\hline $\begin{array}{l}\mathrm{G} \text {-Diseases of the nervous } \\
\text { system }\end{array}$ & $\begin{array}{l}\text { G00-G14; G20-G32; G35-G37; } \\
\text { G40-47; G50-64; G70-73; } \\
\text { G80-G83; G90-G99 }\end{array}$ & 561,054 & 123.2 & $(123.5)$ & 40.1 & 70.6 & 162.2 & 188.6 \\
\hline $\begin{array}{l}\mathrm{H}-\text { Diseases of the eye and } \\
\text { adnexa and diseases of the ear } \\
\text { and mastoid process }\end{array}$ & $\begin{array}{l}\text { H02-H06; H17-H18; H25-H28; } \\
\text { H31-H32; H34-H36; H40-55; } \\
\text { H57; H80, H810; H93, H90- } \\
\text { H93 }\end{array}$ & 448,176 & 98.4 & $(98.6)$ & 47.5 & 25.6 & 112.6 & 394.4 \\
\hline $\begin{array}{l}\text { I-Diseases of the circulatory } \\
\text { system }\end{array}$ & $\begin{array}{l}\text { I05-I06; I10-28; I30-33; } \\
\text { I36-141; I44-I52; I60-I88; I90- } \\
\text { I94; I96-I99 }\end{array}$ & $1,254,427$ & 275.4 & $(275.5)$ & 45.3 & 73.3 & 381.5 & 753.9 \\
\hline $\begin{array}{l}\mathrm{J} \text {-Diseases of the respiratory } \\
\text { system }\end{array}$ & $\begin{array}{l}\text { J30.1; J40-J47; J60-J84; J95, } \\
\text { J97-J99 }\end{array}$ & $1,210,598$ & 265.7 & $(266.3)$ & 42.1 & 209.3 & 298.8 & 381.9 \\
\hline $\begin{array}{l}\mathrm{K} \text {-Diseases of the digestive } \\
\text { system }\end{array}$ & $\begin{array}{l}\text { K25-K27; K40, K43, K50-52; } \\
\text { K58-K59; K71-K77; K86-K87 }\end{array}$ & 329,337 & 72.3 & $(72.6)$ & 44.7 & 41.3 & 86.3 & 157.4 \\
\hline $\begin{array}{l}\text { L-Diseases of the skin and sub- } \\
\text { cutaneous tissue }\end{array}$ & $\mathrm{L} 40$ & 65,469 & 14.4 & $(14.5)$ & 47.8 & 7.9 & 19.3 & 21.7 \\
\hline $\begin{array}{l}\text { M-Diseases of the musculoskel- } \\
\text { etal system and connective tissue }\end{array}$ & $\begin{array}{l}\text { M01-M25; M30-M36; M40- } \\
\text { M54; M60.1-M99 }\end{array}$ & $1,032,808$ & 226.7 & $(227.1)$ & 42.2 & 113.2 & 291.2 & 470.5 \\
\hline $\begin{array}{l}\mathrm{N} \text {-Diseases of the genitourinary } \\
\text { system }\end{array}$ & N18 & 20,162 & 4.4 & $(4.5)$ & 59.4 & 1.0 & 4.8 & 20.0 \\
\hline $\begin{array}{l}\text { Q-Congenital malformations, } \\
\text { deformations and chromosomal } \\
\text { abnormalities }\end{array}$ & Q00-Q56; Q60-Q99 & 124,898 & 27.4 & $(27.5)$ & 41.7 & 33.9 & 23.2 & 16.2 \\
\hline $\begin{array}{l}\mathrm{F} \text { - Mental and behavioural } \\
\text { disorders }\end{array}$ & F00-99 & 683,194 & 150.0 & $(150.7)$ & 41.0 & 135.2 & 150.2 & 223.7 \\
\hline $\begin{array}{l}\text { Having one or more chronic } \\
\text { condition }\end{array}$ & & $2,989,441$ & 656.2 & $(657.2)$ & 45.5 & 480.5 & 771.5 & 953.9 \\
\hline $\begin{array}{l}\text { Mean number of chronic condi- } \\
\text { tions (std. dev) }\end{array}$ & & $2.2(2.8)$ & - & - & $2.0(2.6)$ & $1.1(1.6)$ & $2.7(2.8)$ & $5.3(3.6)$ \\
\hline Depression medicine ${ }^{\mathrm{c}, * *}$ & ATC: N06A & 529,918 & 116.3 & $(116.7)$ & 36.3 & 88.7 & 126.9 & 201.9 \\
\hline Antipsychotic medicine ${ }^{\mathrm{c}, * *}$ & ATC: N05A & 138,625 & 30.4 & $(30.6)$ & 45.7 & 26.1 & 31.9 & 44.8 \\
\hline $\begin{array}{l}\text { Indication prescribed anxiety } \\
\text { medicine }^{\mathfrak{c}, * *}\end{array}$ & $\begin{array}{l}\text { All prescriptions with either indi- } \\
\text { cation code } 163 \text { (for anxiety) or } \\
371 \text { (for anxiety, addictive) }\end{array}$ & 102,568 & 22.5 & $(22.6)$ & 34.5 & 19.9 & 23.7 & 30.1 \\
\hline Heart failure medication ${ }^{\mathrm{c}, * *}$ & $\begin{array}{l}\text { ATC: C01AA05, C03, C07 or } \\
\text { C09A with indication code } 430 \\
\text { (for heart failure) }\end{array}$ & 7468 & 1.6 & $(1.7)$ & 64.6 & 0.1 & 2.0 & 7.5 \\
\hline Ischaemic heart medication $^{\mathrm{c}, * *}$ & ATC: C01A, C01B, C01D, C01E & 129,484 & 28.4 & (28.5) & 51.8 & 1.4 & 32.0 & 147.3 \\
\hline
\end{tabular}


Table 2 (continued)

\begin{tabular}{|c|c|c|c|c|c|c|c|}
\hline \multirow[t]{3}{*}{ Name of condition } & \multirow[t]{3}{*}{ ICD-10 code/definition } & \multicolumn{6}{|c|}{ Number and prevalence } \\
\hline & & \multicolumn{2}{|l|}{ Denmark } & \multirow{2}{*}{$\begin{array}{l}\text { Men } \\
\text { Per cent }\end{array}$} & \multirow{2}{*}{$\begin{array}{l}\text { Age } 16-44 \\
\text { (per 1000) }\end{array}$} & \multirow{2}{*}{$\begin{array}{l}\text { Age } 45-74 \\
\text { (per } 1000)\end{array}$} & \multirow{2}{*}{$\begin{array}{l}\text { Age } \\
75+(\text { per } \\
1000)\end{array}$} \\
\hline & & $N$ & $\begin{array}{l}\text { Per } 1000 \\
\text { (standardised) }\end{array}$ & & & & \\
\hline $\begin{array}{l}\text { All of the five types of medicine } \\
\text { above }\end{array}$ & & 688,006 & 151.0 & 40.4 & 100.2 & 166.1 & 331.1 \\
\hline
\end{tabular}

Standardised rates or standard devitions in brackets

See table with 10-year age intervals in Supplementary Material 2 in the electronic supplementary matertial

Conditions marked 'A' overlap with other conditions and are thus not counted twice [44]

ATC Anatomical Therapeutic Chemical Classification System, ICD-10 International Statistical Classification of Diseases, 10th Revision

${ }^{c}$ Complex defined conditions; see reference for further details [44]

**Two-year prevalence

\section{Results}

\subsection{The Prevalence Rates}

The population's full burden of chronic disease, with all the chronic conditions summarised, was $65.6 \%$ (see Table 2 or Table 3 ). The ten most prevalent conditions were hypertension $(23.3 \%)$, respiratory allergy $(18.5 \%)$, disorders of lipoprotein metabolism (14.3\%), depression (10.0\%), bronchitis $(9.2 \%)$, asthma (7.9\%), type 2 diabetes (5.3\%), COPD $(4.7 \%)$, osteoarthritis of the knee $(3.9 \%)$ and osteoporosis $(3.5 \%) /$ ulcer $(3.5 \%)$; see the overview of conditions solely by overall disease groups in Table 2 and all 199 conditions in Table 3.

In general, prevalence naturally increases with increasing age across most conditions (see also Supplementary Material 2 and 6 with 10-year age intervals). Moreover, patients are relatively older within cancers and endocrine, nutritional and metabolic diseases and diseases of the circulatory system, the eye and adnexa, the ear and mastoid process, and the musculoskeletal system and connective tissue compared to within other conditions. A relatively younger patient population is seen within diseases of the respiratory system (especially allergies and asthma) and mental- and behavioural disorders. Mental disorders actually show a decrease in prevalence in later life. The conditions with the youngest population are, for example, seen within human immunodeficiency virus (HIV) and hepatitis.

Gender differences are seen across conditions, where women are overrepresented within most conditions-except, for example, heart failure and ischaemic heart diseases, stroke, some cancers, diabetes, disturbances in lipoprotein circulation and other lipids, inguinal hernia, hearing loss such as tinnitus, chronic renal failure, sleep disorders, schizophrenia, attention deficit/hyperactivity disorder (ADHD), mental and behavioural disorders due to the use of alcohol, and others. Coherently, women are treated more often than men with medication, except for ischaemic heart medications.

Some further characteristics and differences between conditions are seen and described in Supplementary Material 1-6. This includes geographic regional tables, further age characteristics with mean age and SD, more age intervals, further comments on common selected conditions and regional differences, etc.

\section{Discussion}

Based on the present findings, almost two-thirds of the entire Danish population aged 16 years or above have one or more chronic condition. Seen in the context of previous studies, this is around 10-20 percentage points higher than several other Danish studies [6, 7] as well as international studies $[27,28]$. The overall estimates are also twice the official estimates of the Danish National Board of Health [8]. However, both national and international comparisons are difficult due to differences in methodology and data possibilities, so estimates should be compared with caution. For example, some American studies report that about 50\% of the US population has a chronic condition [52, 53], but reliable overall estimates are difficult to obtain as to why improvement has been recommended [17]. Furthermore, as the US often has higher disease prevalence than the EUoften differing by 20-100\% across different conditions [54] - the present study suggests that the US estimates might be even higher.

\subsection{Strengths and Limitations}

The strength of this study is the detailed, full nationwide register-based collection and categorisation of all data on actual chronic conditions and treatments for Danes in public 


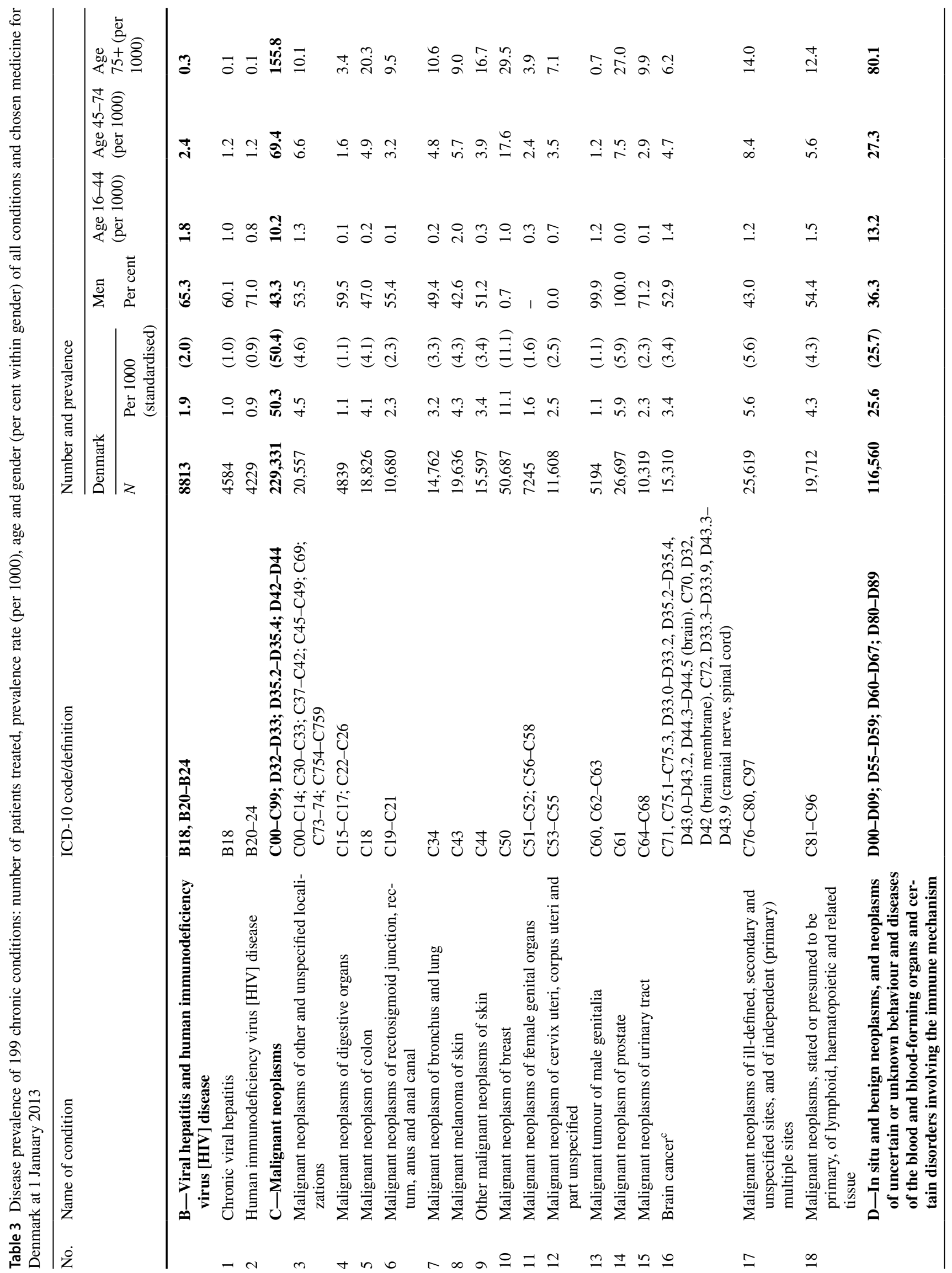




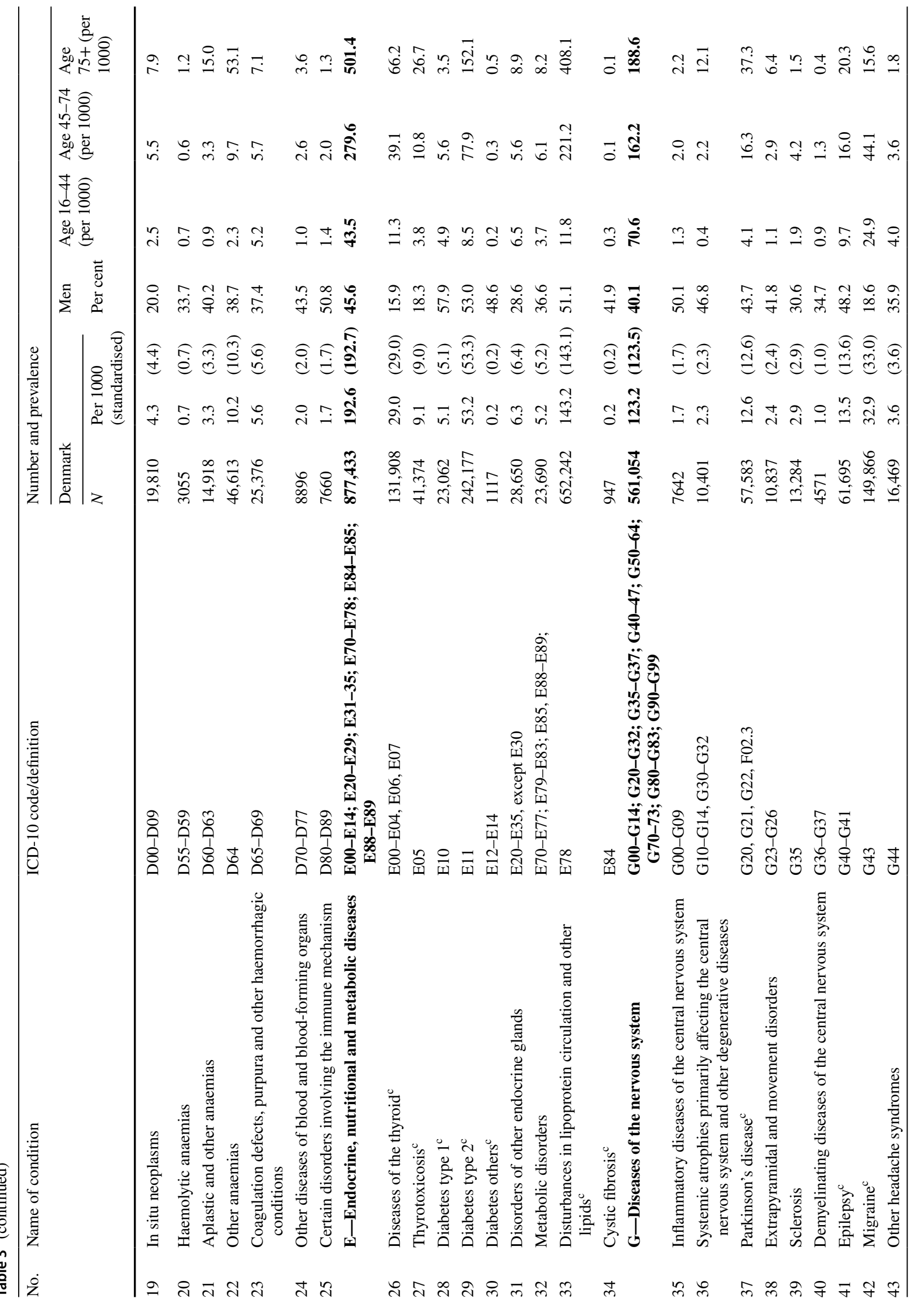




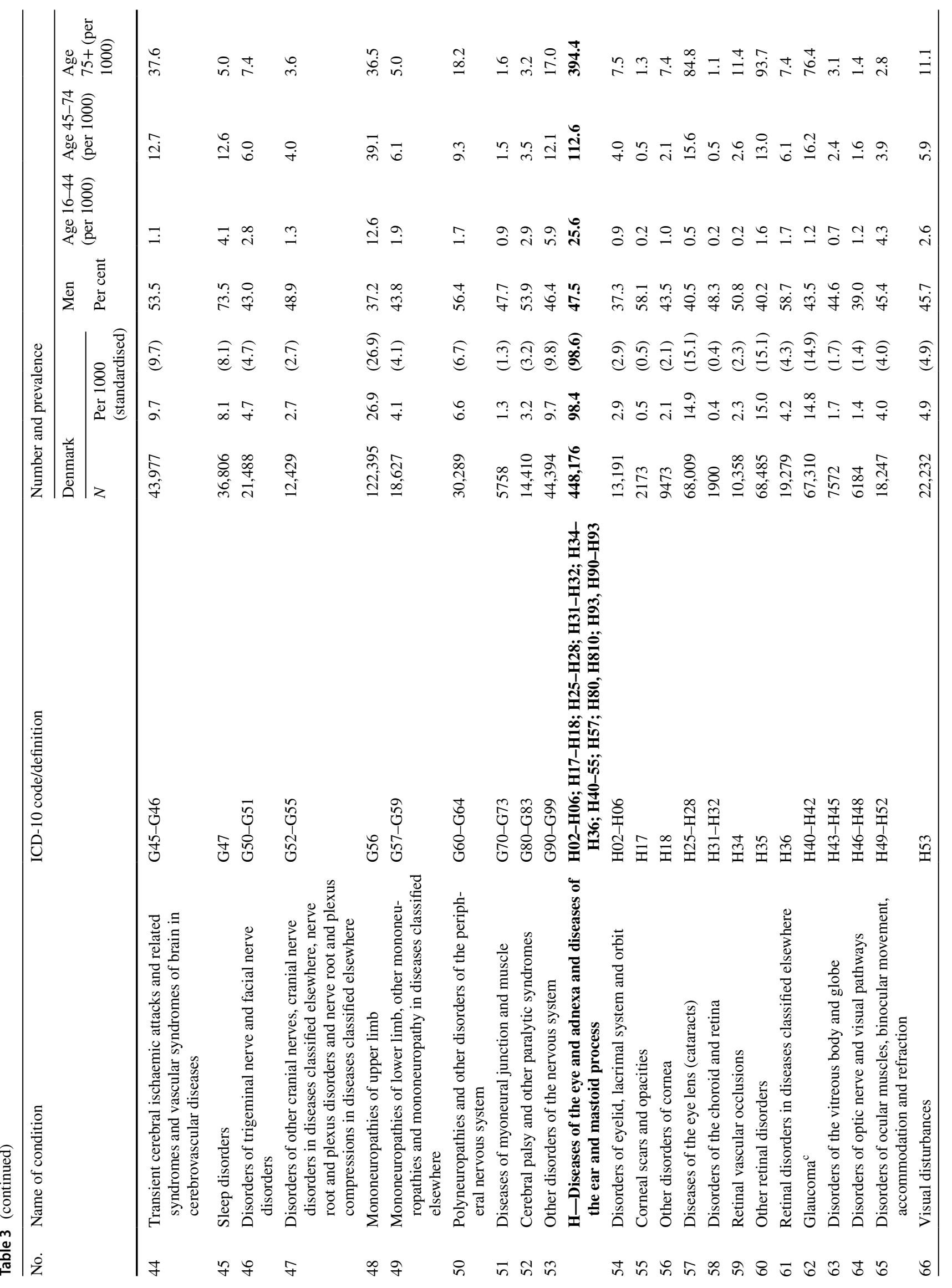




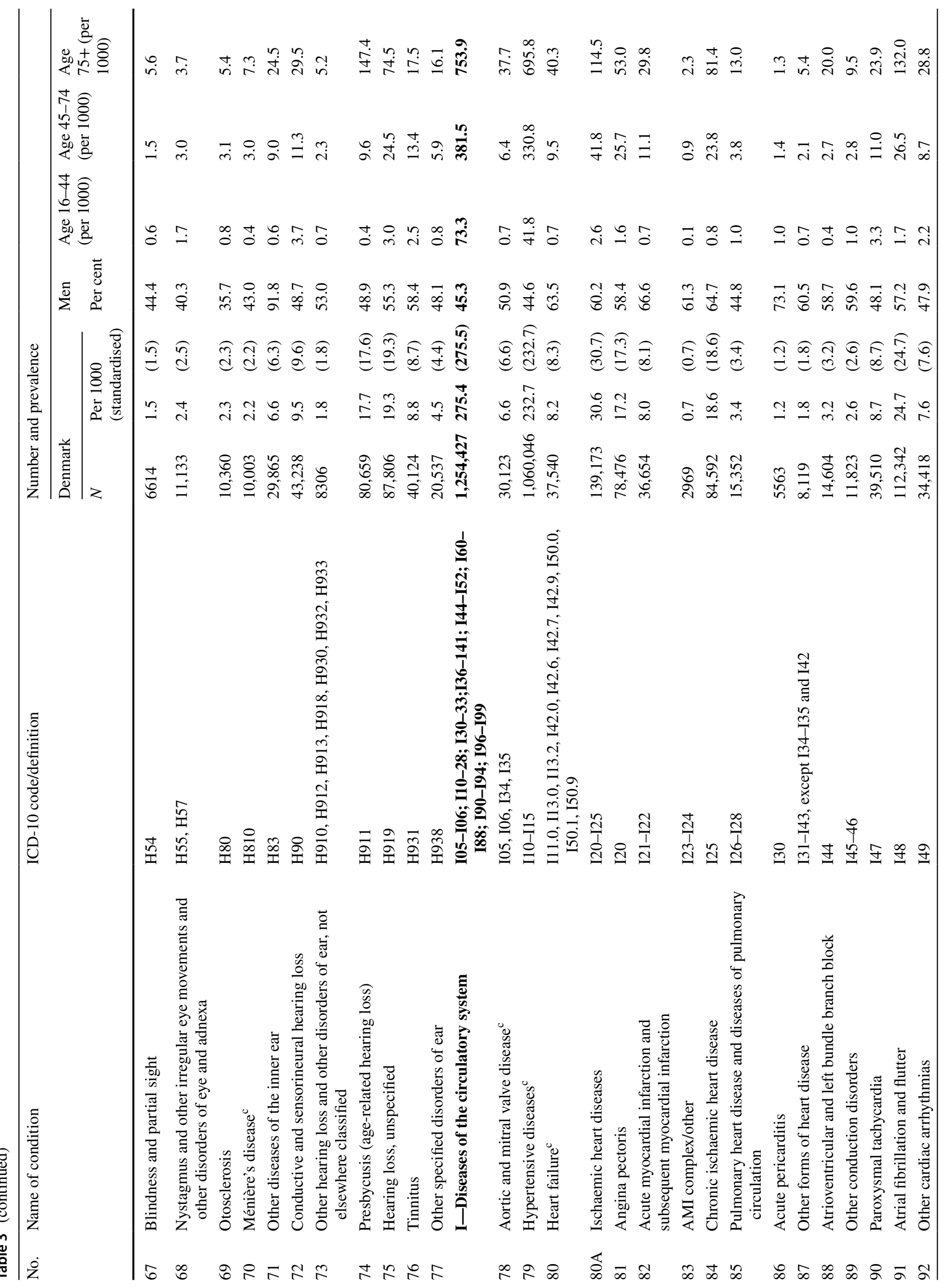




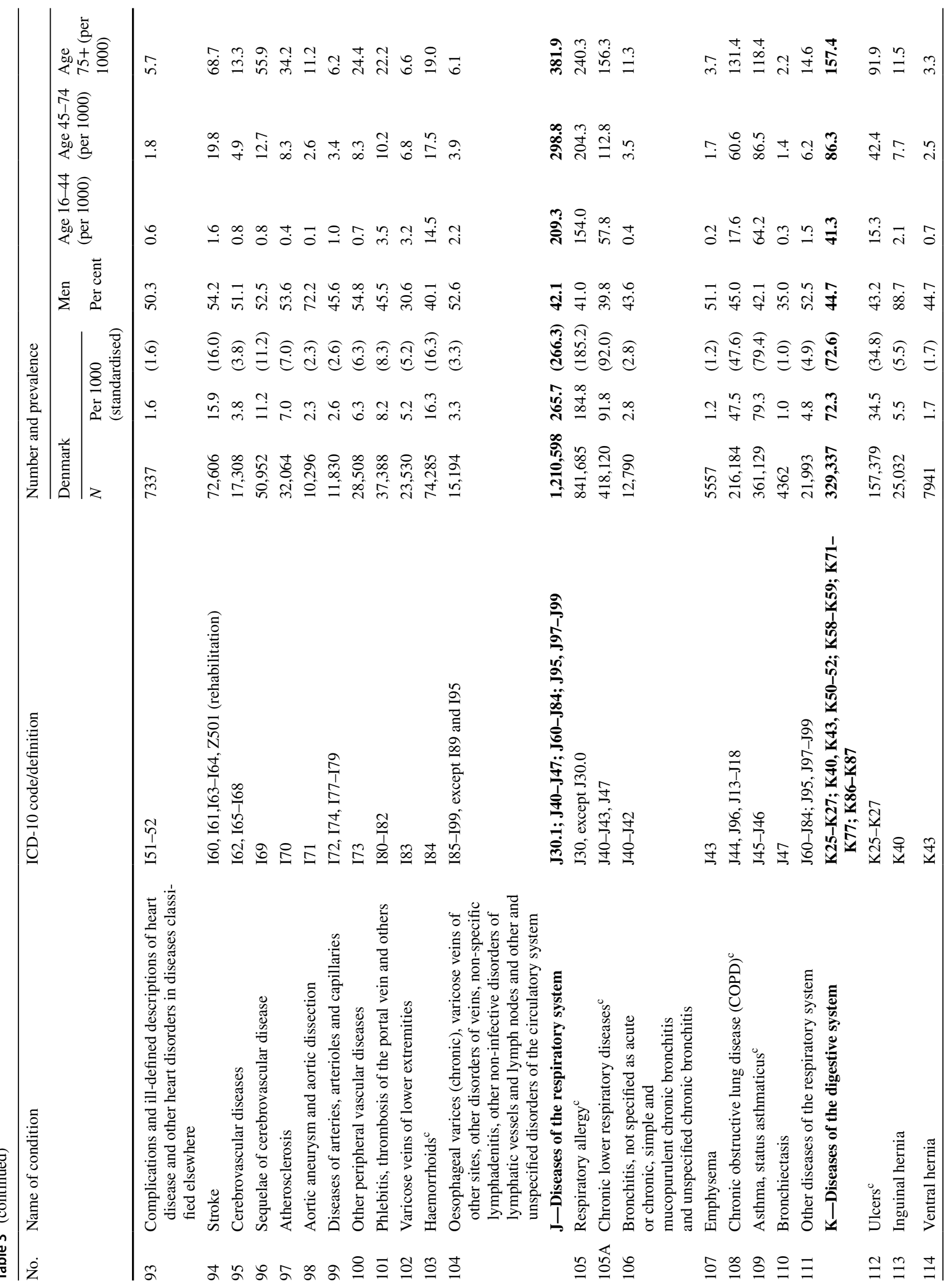




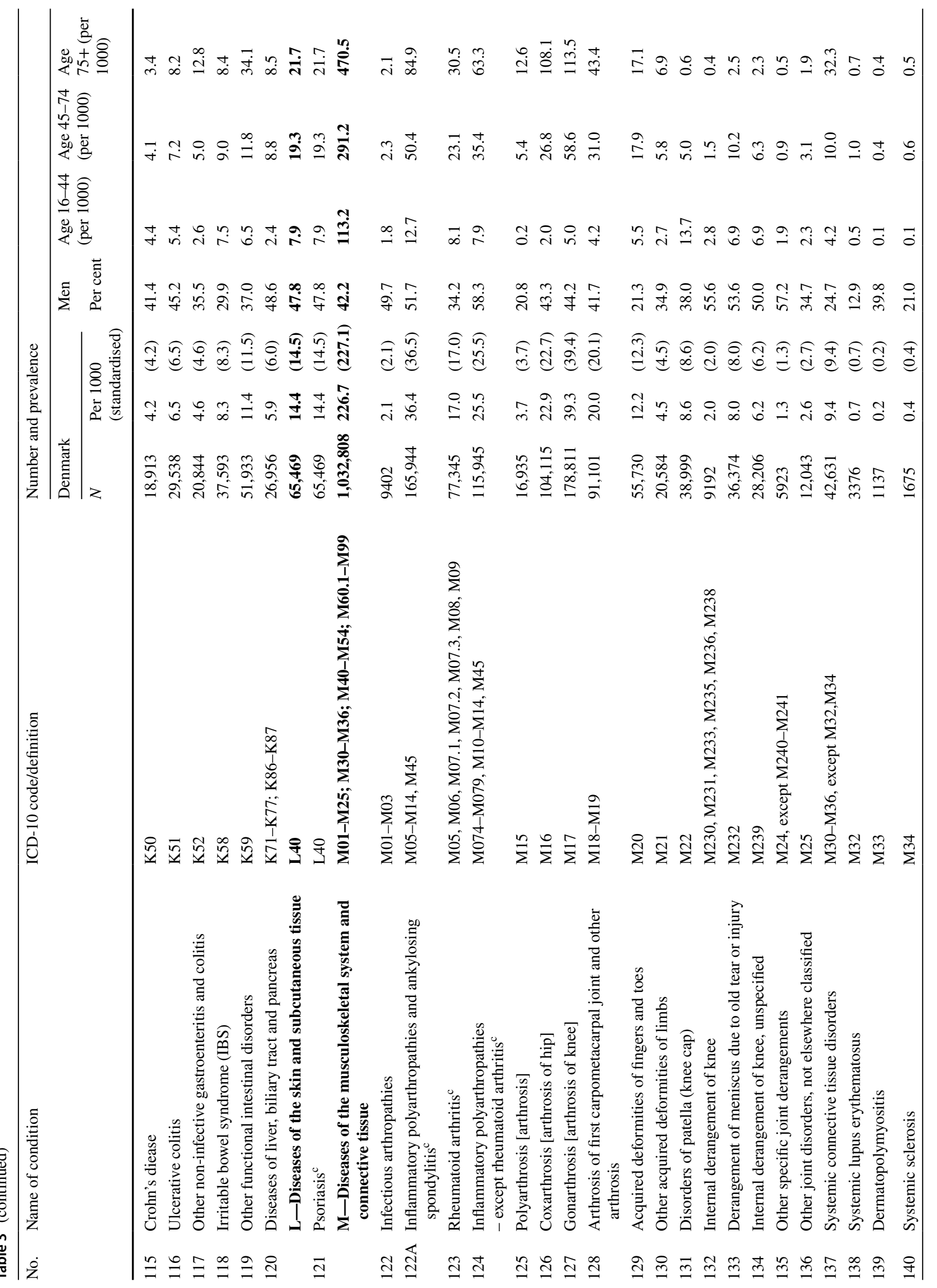




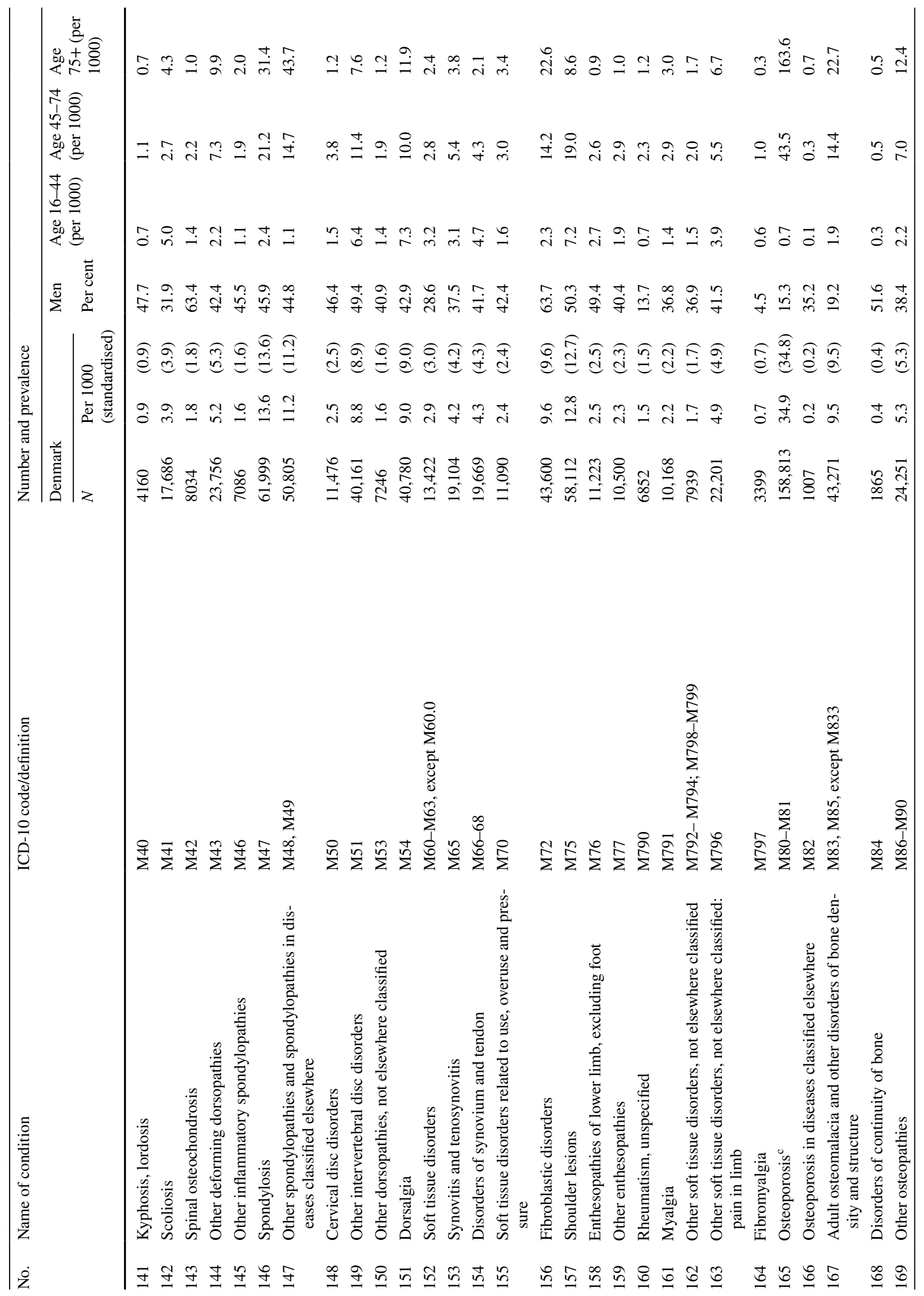




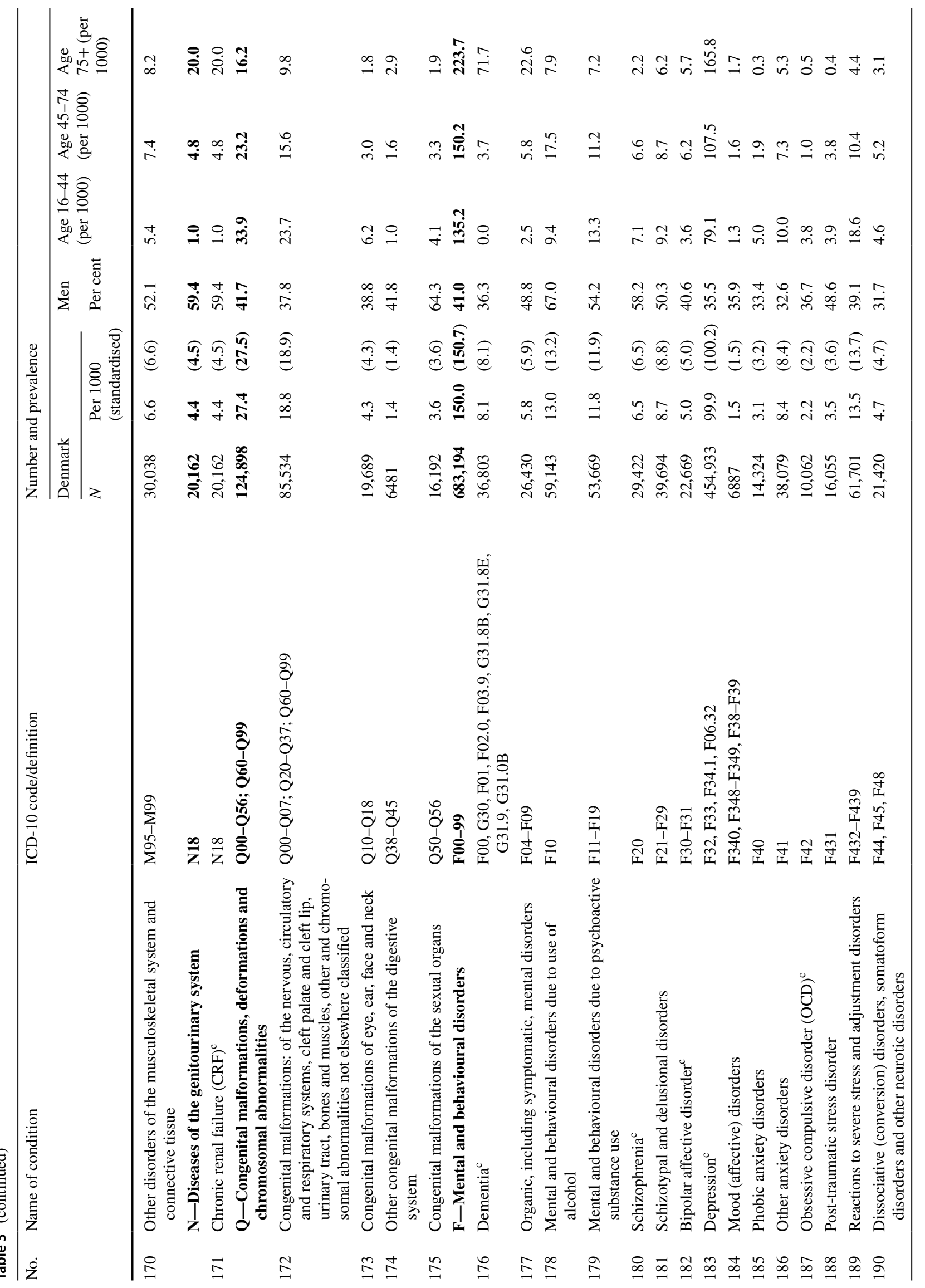




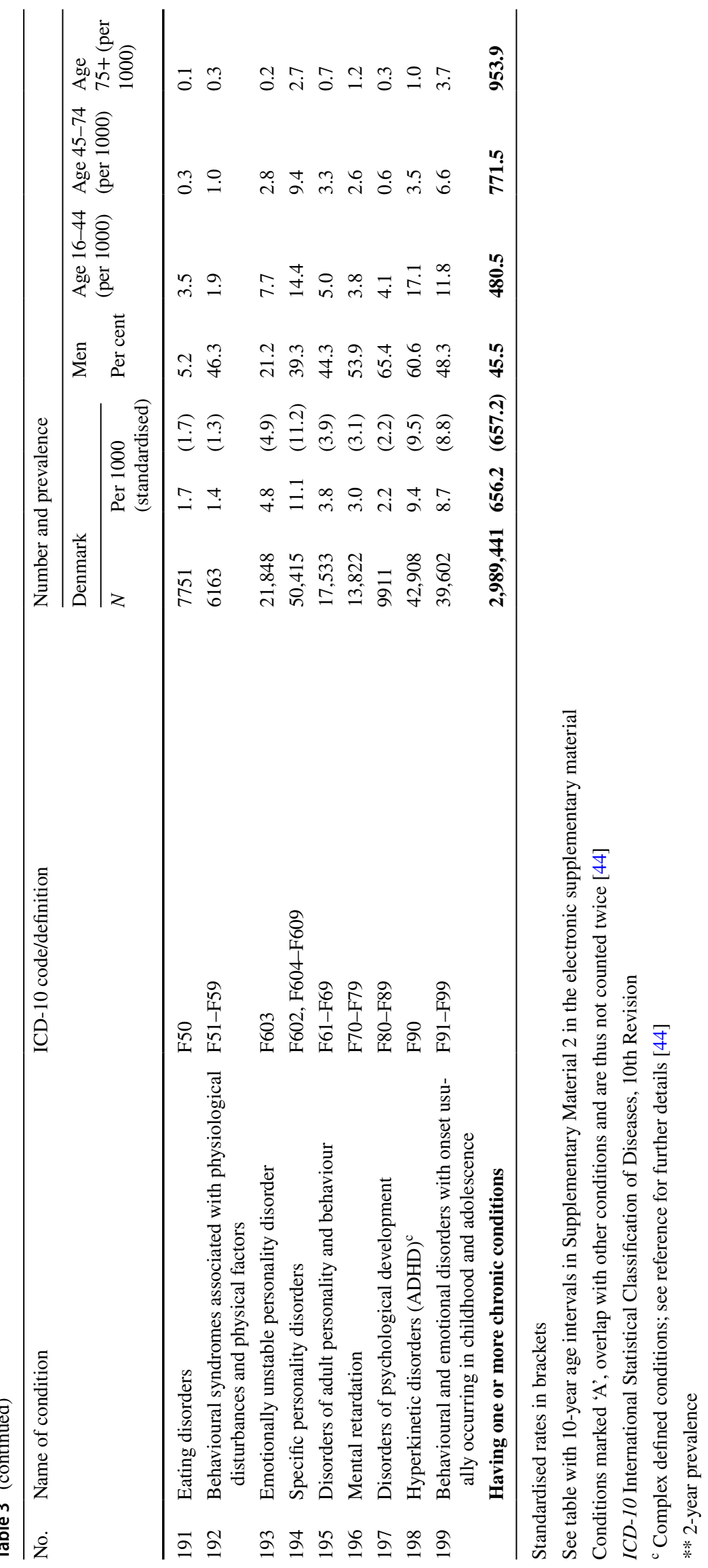


and private healthcare. Several limitations exist, however, one being the obvious fact that being treated for a chronic condition is not necessarily the same as being truly ill. There may be cases of defensive medicine or patients being treated on suspicion of a chronic disease, or even wrong (over-) diagnosis.

As found in previous studies, one of the main limitations of register studies in general is the opposite, i.e. not being able to identify either chronic patients who have not been treated or diagnosed at any time or patients with self-treated conditions, who consequently are not reported in hospital or other registers (i.e. data source limitations, etc.) [44, 55]. This may lead to under-reporting of some less severe chronic conditions, such as asthma, allergies, COPD and type 2 diabetes, which are mostly treated in primary care where there is no reporting of diagnoses. The same might apply for other conditions such as glaucoma, cataracts, agerelated hearing loss, other eye and ear conditions, and less severe mental conditions that are untreated, such as mild forms of depression or anxiety [44]. Thus, differences in the present study are compared with the national self-reported prevalence rates for 2013 for 18 broadly defined conditions where possible, since they cover a wide range of conditions of importance for assessment [6]. In comparison, differences and limitations of register-based definitions might be found within four of the 18 conditions: osteoarthritis, migraine/ headache, tinnitus and cataracts. These conditions are discussed in more detail in Supplementary Material 3. All in all, these register-based less severe conditions may not be sufficiently estimated at this time, which is why registerbased prevalence will be underestimated and should be used with caution.

While some estimated conditions show limitations compared to self-reported conditions, most other conditions, such as hypertension, rheumatoid arthritis, osteoporosis, diabetes, COPD, bronchitis and other lung diseases, cancers, heart condition and stroke, all have higher or slightly higher register-based than self-reported prevalence [6], as well as estimates in line with other studies [7, 10, 33, 55, 56]. The same applies to mental conditions overall, which typically have a lower survey response [57], which could explain the lower self-reported prevalence. Added to the fact that these estimates are free of self-reported bias, this clearly strengthens the reliability of most register-based conditions reported, not to mention the enhanced precision of doctorreported diagnoses.

However, similar to non-registration issues in community-based surveys, misclassification issues also exist in register studies as sources of bias. Reasons for this include different coding practices between hospitals [30], different access to specialists, clinical disagreements, different clinical and administrative practices and interpretation of the ICD-10 criteria [58]. However, we do not have evidence of systemic misclassification. On the contrary, studies have validated reported diagnoses from registers for several psychiatric and somatic conditions, with good overall results [55, 59-64]. Nevertheless, the estimates of some complexaetiology, ill-defined and debated rheumatoid conditions such as fibromyalgia and chronic fatigue syndrome, even though common, should be used with caution since they are clearly under-reported compared to other studies $[58,65$, 66]. Further discussion and references regarding the validity of diagnosis codes in registers can be found elsewhere [44].

In summary, the prevalence of some less severe conditions may be underestimated in register studies [55]. On the other hand, community-based self-reported studies may underestimate, especially, the more severe conditions due to, among other things, non-responders as well as people living in institutions or jails, homeless people, and those currently in inpatient treatment. Existing studies have already shown varying or poor overlap between self-reports and hospital reports [67], some concluding that the use of self-reports is less reliable in cases of, for example, stroke and ischaemic heart disease [68,69], while severe conditions [67] such as cancers cannot reliably be self-diagnosed. Thus, a strength of the current study is that moderate or severe conditions are estimated more accurately and are naturally free of the bias of self-reported conditions. From this perspective, community-based survey studies contrast with and complement register studies [55].

Another strength of the study is that the definitions used were evaluated by epidemiologists and clinicians to strengthen reliability and provide the best possible representation [44]. In addition, the long register time periods are noticeable strengths compared to other register studies [7, 24, 26, 29-31]. Lastly, the use of a complete population of $4,555,439$ people, not to mention the large number of ICD10 doctor-reported conditions included, is another strength not or rarely seen in other studies.

\subsection{Implications}

Existing international register studies usually help determine current disease burden with implications for, for example, the funding of new treatments or others-but usually not multiple conditions [70-72].

The prevalence estimates of the current study provide unbiased, independent important basic information regarding the burden of disease for use in healthcare planning, as well as economic, aetiological and other research for a broad range of conditions. As it is based on uniform methodology within a single study, it also makes reliable comparisons, contrary to most existing studies. In many types of health economic studies, such as analyses of cost of illness and the budgetary consequences of the introduction of new health 
technologies, economic calculations may not provide an accurate, reliable picture if based on invalid information. This comprehensive catalogue of prevalence information of nationwide chronic conditions enables comprehensive comparisons of chronic diseases for policymakers, patient associations and researchers. Thus, it may serve as an offthe-shelf tool for decision makers and researchers for health economic modelling.

\subsection{Future Studies}

The World Health Organization (WHO) have recommended further improvement in data surveillance of chronic conditions worldwide [17]; in addition, other studies have criticised, as well as recommended, methodological improvements [73-76]. Future studies should compare these prevalence rates based on actual patient pathways and registrations of treatment with other methods for estimating disease prevalence. Future studies could also focus on the development over time of disease burden, including the newest register data and analysis of possible trends in diagnosis or possible over-diagnosis. Moreover, while there are several studies exploring the coherence between self-reported conditions and hospital records, we found no studies assessing whether less severe self-reported conditions are more accurately estimated than register-reported conditions. Further studies should be carried out to assess whether chosen less severe self-reported conditions are estimated accurately, and if so, how register and self-reported study designs could best complement each other and for which conditions.

\section{Conclusions}

The current study provides a catalogue of prevalence for 199 different doctor-reported chronic conditions and groups of conditions by gender, based on a complete nationwide population sample.

To the best of the authors' knowledge, this study provides the most comprehensive descriptive register study of the prevalence of treatment of chronic conditions. Hence, the overall prevalence rate found is higher than that found in several previous studies, indicating that almost two-thirds of the entire Danish population aged 16 years or above either have a hospital diagnosis and/or are in medical treatment for one or more chronic condition.

Acknowledgements Special thanks to data management specialists Ole Schou Rasmussen and Thomas Mulvad Larsen from the North Denmark Region, and Niels Bohrs Vej, 9220 Aalborg OE, Denmark, for very useful and helpful suggestions and assistance in data management and SAS programming of the definitions, which has been much appreciated.

Author Contributions All authors contributed to the study design. MFH did all data collection and programming and drafted the manuscript. All authors discussed and interpreted empirical findings. Critical manuscript revision and final approval of the manuscript was done by all authors.

Data Availability Statement Due to the European General Data Protection Regulation (GDPR) and Danish data protection laws, it is not possible to provide the individually based, personal data of the current study directly. However, researchers can apply to Statistics Denmark for access to the data described in the "Methods" section. Thus, the same data of the current study can be provided via Statistics Denmark if the applicant fulfils legal and other requirements. See https://www.dst.dk/ $\mathrm{da} / \mathrm{TilSalg} /$ Forskningsservice. Software codes can be provided by the author when relevant, and data can be legally accessed, etc.

\section{Compliance with Ethical Standards}

Funding The project was supported financially by the North Denmark Region, the Tax Foundation (public) and Aalborg University.

Conflict of interest Michael Falk Hvidberg: None declared. Soeren Paaske Johnsen: None declared. Michael Davidsen: None declared. Lars Ehlers: None declared.

Open Access This article is distributed under the terms of the Creative Commons Attribution-NonCommercial 4.0 International License (http://creativecommons.org/licenses/by-nc/4.0/), which permits any noncommercial use, distribution, and reproduction in any medium, provided you give appropriate credit to the original author(s) and the source, provide a link to the Creative Commons license, and indicate if changes were made.

\section{References}

1. Makady A, ten Ham R, de Boer A, Hillege H, Klungel O, Goettsch W. Policies for use of real-world data in health technology assessment (HTA): a comparative study of six HTA agencies. Value Health [Internet]. Elsevier Inc. 2017;20:520-32. https:// doi.org/10.1016/j.jval.2016.12.003.

2. Garrison LP, Neumann PJ, Erickson P, Marshall D, Mullins $C D$. Using real-world data for coverage and payment decisions: the ISPOR Real-World Data Task Force report. Value Health [Internet]. International Society for Pharmacoeconomics and Outcomes Research (ISPOR). 2007;10:326-35. https://doi.org /10.1111/j.1524-4733.2007.00186.x.

3. Mauskopf J, Earnshaw SR, Brogan A, Wolowacz SBT. Budgetimpact analysis of health care interventions. Manchester: Adis; 2017.

4. Angelis A, Tordrup D, Kanavos P. Socio-economic burden of rare diseases: a systematic review of cost of illness evidence. Health Policy (New York) [Internet]; Elsevier Ireland Ltd. 2015;119:964-79. https://doi.org/10.1016/j.healt hpol.2014.12.016.

5. Faleiros DR, Álvares J, Almeida AM, de Araújo VE, Andrade EIG, Godman BB, et al. Budget impact analysis of medicines: updated systematic review and implications. Expert Rev 
Pharmacoecon Outcomes Res [Internet]. 2016;16:257-66. https ://doi.org/10.1586/14737167.2016.1159958.

6. Christensen AI, Davidsen M, Ekholm O, Pedersen PV, Juel K. Danskernes sundhed-den nationale sundhedsprofil 2013 [Danes health - the national health profile 2013] [Internet]. Sundhedsstyrelsen [National Board Heal. Copenhagen K, Denmark; 2014. http://www.si-folkesundhed.dk/Udgivelser/ Bøgerograpporter/2014/Danskernessundhed-dennationalesun dhedsprofil2013.aspx.

7. Robinson KM, Juel Lau C, Jeppesen M, Vind AB, Glümer C. Kroniske sygdomme-forekomst af kroniske sygdomme og forbrug af sundhedsydelser i Region Hovedstaden v2.0 [Chronic diseases - prevalence of chronic diseases and use of health services in the Capital Region v2.0] [Internet]. Forskningscenter Forebygg. og Sundh. [Research Cent. Prev. Heal. Glostrup, Denmark; 2012. https://www.regionh.dk/fcfs/publikationer/ Documents/Kroniskesygdomme-forekomstafkroniskesygdom meogforbrugafsundhedsydelseriRegionHovedstaden.pdf.

8. Sundhedsstyrelsen [Danish National Board of Health]. Kronisk sygdom [Chronic Illness] [Internet]; 2017. https://www.sst.dk/da/ sygdom-og-behandling/kronisk-sygdom\#. Cited 25 May 2017.

9. Rosendahl Jensen HA, Davidsen M, Ekholm O, Christensen AI. Danskernes Sundhed-Den Nationale Sundhedsprofil 2017 [Danes health - the national health profile 2017] [Internet]. Sundhedsstyrelsen [National Board Heal. Copenhagen K; 2018. http:// www.si-folkesundhed.dk/Udgivelser/B $\emptyset$ gerograpporter/2018/ DanskernesSundhed.DenNationaleSundhedsprofil2017.aspx.

10. Lau C, Lykke M, Andreasen A, Bekker-Jeppesen M, Buhelt L, Robinson K, et al. Sundhedsprofil 2013-Kronisk Sygdom [Health Profile 2013-Chronic Disease] [Internet]. Glostrup Hospital, Nordre Ringvej 57, Afsnit 84-85, 2600 Glostrup, Copenhagen Denmark e-mail: fcfs@ regionh.dk, Denmark; 2015. https:// www.regionh.dk/fcfs/publikationer/Documents/Sundhedsprofil2 013-Kronisksygdom.pdf. Cited 2 July 2015.

11. Naghavi M, Wang H, Lozano R, Davis A, Liang X, Zhou M, et al. Global, regional, and national age-sex specific all-cause and cause-specific mortality for 240 causes of death, 1990-2013: a systematic analysis for the Global Burden of Disease Study 2013. Lancet [Internet]. Elsevier Ltd. 2015;385:117-71. https:// doi.org/10.1016/S0140-6736(14)61682-2.

12. Murray CJL, Ezzati M, Flaxman A. Supplementary appendixcomprehensive systematic analysis of global epidemiology: definitions, methods, simplification of DALYs, and comparative results from the Global Burden of Disease Study 2010. Lancet [Internet]. 2012;380:2063-66. http://linkinghub.elsevier.com/retrieve/pii/ S0140673615606924.

13. Murray CJ, Ezzati M, Flaxman AD, Lim S, Lozano R, Michaud C, et al. GBD 2010: design, definitions, and metrics. Lancet [Internet]. 2012;380:2063-6. http://linkinghub.elsevier.com/retrieve/pii/ S0140673612618996.

14. Vos T, Barber RM, Bell B, Bertozzi-Villa A, Biryukov S, Bolliger I, et al. Global, regional, and national incidence, prevalence, and years lived with disability for 301 acute and chronic diseases and injuries in 188 countries, 1990-2013: a systematic analysis for the Global Burden of Disease Study 2013. Lancet [Internet]. 2015;386:743-800. http://linkinghub.elsevier.com/retrieve/pii/ S0140673615606924.

15. World Health Organization (WHO). World Health Statistics 2015 [Internet]. World H. 2015. p. 164. http://apps.who.int/iris/bitst ream/10665/148114/1/9789241564854_eng.pdf?ua=1. Cited 22 Apr 2016.

16. World Health Organization (WHO). Global status report on noncommunicable diseases 2014 [Internet]. World Health; 2014. http://www.who.int/nmh/publications/ncd-status-report-2014/ en/. Cited 18 Nov 2015.
17. World Health Organization (WHO). Global status report on noncommunicable diseases 2010 [Internet]. World Health; 2010. http://www.who.int/nmh/publications/ncd_report2010/en/. Cited 18 Nov 2015.

18. Murray CJL, Barber RM, Foreman KJ, Ozgoren AA, Abd-Allah F, Abera SF, et al. Global, regional, and national disability-adjusted life years (DALYs) for 306 diseases and injuries and healthy life expectancy (HALE) for 188 countries, 1990-2013: quantifying the epidemiological transition. Lancet [Internet]. 2015;386:2145-91. http://www.thelancet.com/journals/lancet/article/PIIS01406736(15)61340-X/abstract.

19. Murray CJL, Vos T, Lozano R, Naghavi M, Flaxman AD, Michaud C, et al. Disability-adjusted life years (DALYs) for 291 diseases and injuries in 21 regions, 1990-2010: a systematic analysis for the Global Burden of Disease Study 2010. Lancet [Internet]. 2012;380:2197-223. http://linkinghub.elsevier.com/ retrieve/pii/S0140673612616894.

20. Murray CJL, Lopez AD. The global burden of disease: a comprehensive assessment of mortality and disability from deceases, injuries and risk factors in 1990 and projected to 2010 [Internet]. Harvard Univ. Press. World Health Organization; 1996. http:// apps.who.int/iris/bitstream/10665/41864/1/0965546608_eng.pdf.

21. Schiller JS, Lucas JW, Ward BW, Peregoy JA. Summary health statistics for U.S. adults: National Health Interview Survey, 2011. Vital Heal Stat [Internet]. 2012;10:1-207. http://www.ncbi.nlm. nih.gov/pubmed/22834228.

22. Garrett N, Martini EM. The boomers are coming: a total cost of care model of the impact of population aging on the cost of chronic conditions in the United States. Dis Manag [Internet]. 2007;10:51-60. http://www.ncbi.nlm.nih.gov/pubmed/17444790. Cited 11 Apr 2015.

23. Sundhedsstyrelsen [Danish National Board of Health]. Kronisk sygdom: patient, sundhedsvæsen og samfund [Chronic conditions: patient, health care and society] [Internet]. Natl. Boards Heal. Copenhagen: Sundhedsstyrelsen; 2005. http://www.sst.dk/ publ/Publ2005/PLAN/Kronikere/Kronisk_sygdom_patient_sundh edsvaesen_samfund.pdf. Cited 1 May 2015.

24. Esteban-Vasallo M, Dominguez-Berjon M, Astray-Mochales J, Genova-Maleras R, Perez-Sania A, Sanchez-Perruca L, et al. Epidemiological usefulness of population-based electronic clinical records in primary care: estimation of the prevalence of chronic diseases. Fam Pract [Internet]. 2009;26:445-54. http://www.ncbi. nlm.nih.gov/pubmed/19815673. Cited 20 Mar 2015.

25. Epping-Jordan J, Pruitt S, Bengoa R, Wagner E. Improving the quality of health care for chronic conditions. Qual Saf Health Care [Internet]. 2004;13:299-305. http://qualitysafety.bmj.com/looku p/doi/10.1136/qshc.2004.010744. Cited 22 Mar 2015.

26. Wiréhn A-BE, Karlsson HM, Carstensen JM. Estimating disease prevalence using a population-based administrative healthcare database. Scand J Public Health [Internet]. 2007;35:424-31. http://www.ncbi.nlm.nih.gov/pubmed/17786807. Cited 22 Apr 2015.

27. Schneider KM, O'Donnell BE, Dean D. Prevalence of multiple chronic conditions in the United States' Medicare population. Health Qual Life Outcomes [Internet]. 2009;7:82. http:// www.pubmedcentral.nih.gov/articlerender.fcgi?artid $=27480$ 70\&tool=pmcentrez\&rendertype $=$ abstract. Cited 20 Apr 2014.

28. Vogeli C, Shields AE, Lee T a, Gibson TB, Marder WD, Weiss $\mathrm{KB}$, et al. Multiple chronic conditions: prevalence, health consequences, and implications for quality, care management, and costs. J Gen Intern Med [Internet]. 2007;22:391-5. http://www.pubme dcentral.nih.gov/articlerender.fcgi?artid=2150598\&tool=pmcen trez\&rendertype $=$ abstract. Cited 26 Mar 2014.

29. Klinisk Epidemiologisk Afdeling [Department of Clinical Epidemiology]. Sygehuskontakter og lægemiddelforbrug for udvalgte kroniske sygdomme i Region Nordjylland [Hospital contacts and 
drug consumption for selected chronic diseases in North Jutland] [Internet]. Dep Clin Epidemiol. Denmark; 2007. http://www.kea. au.dk/file/pdf/36.pdf. Cited 1 May 2014.

30. Sundhedsstyrelsen [Danish National Board of Health]. Beskrivelse af Sundhedsstyrelsens monitorering af kronisk sygdom [Description of National Board of Health's monitoring of chronic disease] [Internet]. Natl Board Health; 2012. http://www.ssi.dk/ / media/Indhold/DK-dansk/Sundhedsdataogit/NSF/Dataformidling/ Sundhedsdata/Kroniker/MetodebeskrivelseafSundhedsstyrelse nsmonitoreringafkronisksygdom.ashx. Cited 15 June 2015.

31. Statens Serum Institute. Monitorering af kronisk sygdom hos Statens Serum Institut [Monitoring of chronic disease at Statens Serum Institute] [Internet]. Statens Serum Inst.; 2012. http://www. ssi.dk/Sundhedsdataogit/Sundhedsvaesenetital/Monitoreringer/ Kronisksygdom/Monitorering-Kronisksygdom2011.aspx. Cited 10 Nov 2014.

32. Hommel K, Rasmussen S, Madsen M, Kamper A-L. The Danish Registry on Regular Dialysis and Transplantation: completeness and validity of incident patient registration. Nephrol Dial Transplant [Internet]. 2010;25:947-51. http://www.ncbi.nlm.nih.gov/ pubmed/19861312. Cited 1 May 2015.

33. Carstensen B, Kristensen JK, Marcussen MM, Borch-Johnsen K. The National Diabetes Register. Scand J Public Health [Internet]. 2011;39:58-61. http://www.ncbi.nlm.nih.gov/pubme d/21775353. Cited 1 May 2015.

34. Info@ norpen.org. Nordic PharmacoEpidemiological Network (NorPEN) [Internet]. http://www.norpen.org/pages/publicatio ns.html. Cited 16 Apr 2019.

35. Wettermark B, Persson ME, Wilking N, Kalin M, Korkmaz S, Hjemdahl $\mathrm{P}$, et al. Forecasting drug utilization and expenditure in a metropolitan health region. BMC Health Serv Res. 2010;10.

36. Eriksson I, Wettermark B, Persson M, Edström M, Godman B, Lindhé A, et al. The early awareness and alert system in Sweden: history and current status. Front Pharmacol. 2017;8:1-8.

37. Olsen J, Basso O, Sørensen HT. What is a population-based registry? Scand J Public Health [Internet]. 1999;27:78. http:// sjp.sagepub.com/content/27/1/78.long.

38. Kamper-Jørgensen F. New editor and new publisher for the Scandinavian Journal of Public Health. Scand J Public Health. 2008;36:1-2.

39. Lynge E, Sandegaard JL, Rebolj M. The Danish National Patient Register. Scand J Public Health [Internet]. 2011;39:30-3. http:// www.ncbi.nlm.nih.gov/pubmed/21775347. Cited 1 May 2015.

40. Mors O, Perto GP, Mortensen PB. The Danish Psychiatric Central Research Register. Scand J Public Health [Internet]; 2011;39:54-7. Available from: http://www.ncbi.nlm.nih.gov/ pubmed/21775352. Cited 4 June 2015.

41. Sahl Andersen J, De Fine Olivarius N, Krasnik A. The Danish National Health Service Register. Scand J Public Health [Internet]; 2011;39:34-7. http://www.ncbi.nlm.nih.gov/pubme d/21775348. Cited 2 May 2015.

42. Wallach Kildemoes H, Toft Sorensen H, Hallas J. The Danish National Prescription Registry. Scand J Public Health [Internet]; 2011;39:38-41. http://www.ncbi.nlm.nih.gov/pubmed/21775 349. Cited 29 Apr 2014.

43. Pedersen CB, Gøtzsche H, Møller JO, Mortensen PB. The Danish Civil Registration System. A cohort of eight million persons. Dan Med Bull [Internet]. 2006;53:441-9. http://www.ncbi.nlm. nih.gov/pubmed/17150149.

44. Hvidberg MF, Johnsen SP, Glumer C, Petersen KD, Olesen A V., Ehlers L. Catalog of 199 register-based definitions of chronic conditions. Scand J Public Health [Internet]. 2016;44:462-79. http://sjp.sagepub.com/content/early/2016/04/19/1403494816 641553.full.

45. Hvidberg MF, Johnsen SP, Glumer C, Petersen KD, Olesen AV, Ehlers L. Supplementary material: process, content and considerations of the medical review and ratification regarding register-based definitions of chronic conditions (to "Catalog of 199 register-based definitions of chronic conditions"). Scand J Public Health [Internet]. 2016;44:462-79. http://sjp.sagep ub.com/content/early/2016/04/19/1403494816641553/suppl/ DC1.

46. Hvidberg M. A framework for identifying disease burden and estimating health-related quality of life and prevalence rates for 199 medically defined conditions. Aalborg: Aalborg University Press; 2016.

47. Paez KA, Zhao L, Hwang W. Rising out-of-pocket spending for chronic conditions: a ten-year trend. Health Aff [Internet]. 2009;28:15-25. Available from: http://www.ncbi.nlm.nih.gov/ pubmed/19124848. Cited 15 July 2013.

48. Sullivan PW, Ghushchyan V. Preference-based EQ-5D index scores for chronic conditions in the United States. Med Decis Making [Internet]. 2006;26:410-20. http://www.pubmedcent ral.nih.gov/articlerender.fcgi artid $=2634296 \&$ tool=pmcen trez\&rendertype $=$ abstract. Cited 23 Apr 2012.

49. Sullivan PW, Slejko JF, Sculpher MJ, Ghushchyan V. Catalogue of EQ-5D scores for the United Kingdom. Med Decis Making [Internet]. 2011;31:800-4. http://www.ncbi.nlm.nih.gov/pubme d/21422468. Cited 4 June 2012.

50. Naing NN. Easy way to learn standardization: direct and indirect methods. Malays J Med Sci [Internet]. 2000;7:10-5. http:// www.pubmedcentral.nih.gov/articlerender.fcgi? artid=34062 $11 \&$ tool $=$ pmcentrez\&rendertype $=$ abstract.

51. Jensen VM, Rasmussen AW. Danish education registers. Scand J Public Health [Internet]. 2011;39:91-4. http://sjp.sagepub.com/ cgi/doi/10.1177/1403494810394715.

52. Ward BW, Schiller JS, Goodman RA. Multiple chronic conditions among US adults: a 2012 update. Prev Chronic Dis [Internet]. 2014;11:130389. http://www.cdc.gov/pcd/issues/2014/13_0389. htm.

53. Centers for Disease Control (CDC). Chronic diseases: the leading causes of death and disability in the United States [Internet]. Chronic Dis. Overv. 2015. http://www.cdc.gov/chronicdisease/ overview/index.htm.

54. Thorpe KE, Howard DH, Galactionova K. Differences in disease prevalence as a source of the U.S.-European health care spending gap. Health Aff [Internet]. 2007;26. http://www.euro.who. int/_data/assets/pdf_file/0008/96632/E93736.pdf.

55. Pedersen CB, Mors O, Bertelsen A, Waltoft BL, Agerbo E, McGrath JJ, et al. A comprehensive nationwide study of the incidence rate and lifetime risk for treated mental disorders. JAMA Psychiatry [Internet]. 2014;71:573. http://www.ncbi.nlm.nih.gov/ pubmed/24806211. Cited 24 May 2014.

56. Christensen J, Vestergaard M, Pedersen MG, Pedersen CB, Olsen $\mathrm{J}$, Sidenius P. Incidence and prevalence of epilepsy in Denmark. Epilepsy Res [Internet]. 2007;76:60-5. http://www.ncbi.nlm.nih. gov/pubmed/17686613.

57. Alonso J, Angermeyer MC, Bernert S, Bruffaerts R, Brugha TS, Bryson H, et al. Prevalence of mental disorders in Europe: results from the European Study of the Epidemiology of Mental Disorders (ESEMeD) project. Acta Psychiatr Scand [Internet]. 2004;109:21-7. http://www.ncbi.nlm.nih.gov/pubmed/15128384.

58. Falk Hvidberg M, Brinth LS, Olesen A V., Petersen KD, Ehlers L. The health-related quality of life for patients with myalgic encephalomyelitis/chronic fatigue syndrome (ME/CFS). Furlan R, editor. PLoS One [Internet]. 2015;10. http://dx.plos.org/10.1371/journ al.pone.0132421.

59. Kessing L. Validity of diagnoses and other clinical register data in patients with affective disorder. Eur Psychiatry [Internet]. 1998;13:392-8. http://www.ncbi.nlm.nih.gov/pubmed/19698654.

60. Pedersen M, Klarlund M, Jacobsen S, Svendsen AJ, Frisch M. Validity of rheumatoid arthritis diagnoses in the Danish National 
Patient Registry. Eur J Epidemiol [Internet]. 2004;19:1097-103. http://www.ncbi.nlm.nih.gov/pubmed/15678789.

61. Phung TKT, Andersen BB, Hoegh P, Kessing LV, Mortensen PB, Waldemar G. Validity of dementia diagnoses in the Danish hospital registers. Dement Geriatr Cogn Disord [Internet]; 2007;24:220-8. http://www.ncbi.nlm.nih.gov/pubmed/17690555. Cited 27 Aug 2014.

62. Bock C, Bukh J, Vinberg M, Gether U, Kessing L. Validity of the diagnosis of a single depressive episode in a case register. Clin Pract Epidemiol Ment Health [Internet]. 2009;5:4. http:// www.pubmedcentral.nih.gov/articlerender.fcgi? artid=26603 21\&tool $=$ pmcentrez\&rendertype $=$ abstract.

63. Uggerby P, Østergaard SD, Røge R, Correll CU, Nielsen J. The validity of the schizophrenia diagnosis in the Danish Psychiatric Central Research Register is good. Dan Med J [Internet]. 2013;60:A4578. http://www.ncbi.nlm.nih.gov/pubmed/23461991.

64. Thygesen SK, Christiansen CF, Christensen S, Lash TL, Sørensen HT. The predictive value of ICD-10 diagnostic coding used to assess Charlson comorbidity index conditions in the populationbased Danish National Registry of Patients. BMC Med Res Methodol [Internet]. BioMed Central Ltd; 2011;11:83. http:// www.pubmedcentral.nih.gov/articlerender.fcgi?artid $=31253$ 88\&tool=pmcentrez\&rendertype $=$ abstract. Cited 27 Aug 2014.

65. Deodhar A, Marcus DA. Fibromyalgia [Internet]. New York: Springer; 2011. http://link.springer. com/10.1007/978-1-4419-1609-9.

66. Branco JC, Bannwarth B, Failde I, Abello Carbonell J, Blotman F, Spaeth M, et al. Prevalence of fibromyalgia: a survey in five European countries. Semin Arthritis Rheum [Internet]. Elsevier Inc.; 2010;39:448-53. http://dx.doi.org/10.1016/j.semarthrit .2008.12.003.

67. Robinson KM, Juel Lau C, Jeppesen M, Vind AB, Glümer C. Kroniske sygdomme - hvordan opgøres kroniske sygdomme [Chronic disease - how is chronic disease defined] [Internet]. Glostrup Hospital, Nordre Ringvej 57, Afsnit 84-85, 2600 Glostrup, Copenhagen Denmark e-mail: fcfs@ regionh.dk, Denmark; 2011. https:// www.regionh.dk/fcfs/publikationer/nyhedsbreve/setember-2014/ PublishingImages/Sider/NyKroniske_sygdomme_metoderapp ort.pdf. Cited 5 May 2014.

68. Carter K, Barber PA, Shaw C. How does self-reported history of stroke compare to hospitalization data in a population-based survey in New Zealand? Stroke [Internet]. 2010;41:2678-80. http:// www.ncbi.nlm.nih.gov/pubmed/20947834. Cited 7 Aug 2014.
69. Bergmann MM, Byers T, Freedman DS, Mokdad A. Validity of self-reported diagnoses leading to hospitalization : a comparison of self-reports with hospital records in a prospective study of american adults. Am J Epidemiol [Internet]. 1998;147:969-77. http://aje.oxfordjournals.org/content/147/10/969.short.

70. Barbosa WB, Costa J de O, de Lemos LLP, Gomes RM, de Oliveira HN, Ruas CM, et al. Costs in the treatment of schizophrenia in adults receiving atypical antipsychotics: an 11-year cohort in Brazil. Appl Health Econ Health Policy [Internet]. Springer International Publishing; 2018;16:697-709. https://doi. org/10.1007/s40258-018-0408-4.

71. Maia Diniz I, Guerra AA Jr, Pires Lovato, de Lemos L, Souza KM, Godman B, Bennie M, et al. The long-term costs for treating multiple sclerosis in a 16-year retrospective cohort study in Brazil. PLoS One. 2018;13:e0199446. https://doi.org/10.1371/journ al.pone.0199446.

72. Godói IP, Da Silva LVD, Sarker AR, Megiddo I, Morton A, Godman B, et al. Economic and epidemiological impact of dengue illness over 16 years from a public health system perspective in Brazil to inform future health policies including the adoption of a dengue vaccine. Expert Rev Vaccines [Internet]. Taylor and Francis; 2018;17:1123-33. https://doi.org/10.1080/14760 584.2018.1546581.

73. Plaß D. The Burden of Disease framework-success story but necessities for adaptations: potentials and challenges when measuring the disease burden of infectious diseases and the disease burden at a sub-national level. Ph.D. dissertation [Internet]. Bielefeld: Universität Bielefeld; 2014. https://pub.uni-bielefeld.de/publi cation/2694785.

74. Polinder S, Haagsma JA, Stein C, Havelaar AH. Systematic review of general burden of disease studies using disability-adjusted life years. Popul Health Metr [Internet]. 2012;10:21. http://www. pophealthmetrics.com/content/10/1/21.

75. Nord E. Disability weights in the Global Burden of Disease 2010: unclear meaning and overstatement of international agreement. Health Policy (New York) [Internet]. Elsevier Ireland Ltd; 2013;111:99-104. http://dx.doi.org/10.1016/j.healt hpol.2013.03.019.

76. Nord E. Uncertainties about disability weights for the Global Burden of Disease study. Lancet Glob Heal [Internet]. Nord. Open Access article distributed under the terms of CC BY-NC-ND; 2015;3:e661-2. http://www.thelancet.com/pdfs/journals/langlo/ PIIS2214-109X(15)00189-8.pdf. 